\title{
Timing and conditions modify the effect of structure liming on clay soil
}

\author{
Jens Blomquist and Kerstin Berglund \\ Department of Soil and Environment, Swedish University of Agricultural Sciences, Uppsala, Sweden \\ e-mail: jens.blomquist@slu.se
}

\begin{abstract}
Two dates (early, normal) for application and incorporation of structure lime to clay soil were examined at four field sites, to test whether early liming had more favourable effects on aggregate stability. Aggregate size distribution measurements revealed a finer tilth at the early liming date (20 August) than the normal date (14 September). Aggregate stability estimated one year later, using as a proxy turbidity in leachate from $2-5 \mathrm{~mm}$ aggregates subjected to two simulated rainfall events, was significantly improved ( $11 \%$ lower turbidity) with early compared with normal liming date. Three years after structure liming, soil structural stability measurements on lysimeters $(15 \mathrm{~cm}$ high, inner diameter $18 \mathrm{~cm}$ ) subjected to repeated simulated rainfall events showed no significant differences in turbidity in leachate between the early and normal liming dates. However, there was a strong interaction between liming date and site indicating different reactions at different sites. Our results suggest that early spreading and incorporation can improve the success of structure liming, but only if soil conditions are favourable.
\end{abstract}

Key words: structure lime, aggregate stability, structural stability, turbidity, phosphorus, timing

\section{Introduction}

Under the EU Water Framework Directive as implemented in Swedish legislation, structure liming qualifies for an environmental subsidy of up to $50 \%$ of the cost, in order to reduce phosphorus losses to surface waters through increased soil aggregate stability. In the period 2010-2020, approximately 60000 hectares of clay soil in Sweden were structure-limed with blends of $\mathrm{CaCO}_{3}$ and $\mathrm{Ca}(\mathrm{OH})_{2}$. In the coming six years it is recommended by the Swedish Water Authorities that close to 500000 hectares of clay soils in Sweden should be structure limed in order to fulfil the commitment of the EU Water Directive (VISS 2021). It is very important that these liming measures are carried out in an appropriate way.

Liming has multiple impacts on soils, affecting chemical, biological and physical properties (Holland et al. 2018). Soil aggregate stability can be influenced by applying different forms of lime, e.g. calcium carbonate (limestone, agricultural lime, $\mathrm{CaCO}_{3}$ ), calcium oxide (quicklime, burnt lime, $\mathrm{CaO}$ ) or calcium hydroxide (hydrated lime, slaked lime, $\mathrm{Ca}(\mathrm{OH})_{2}$ ). The mode of action is probably a result of both chemical form and the calcium ion per se. The speed at which liming alters soil structure is dependent on the solubility and particle size of the added lime, and also on the buffering capacity of the soil (Holland et al. 2018). When structure lime, i.e. $\mathrm{CaO}$ or $\mathrm{Ca}(\mathrm{OH})_{2}$, either in pure form or in mixtures with $\mathrm{CaCO}_{3}$, encounters clay, different reactions take place on microaggregate level. These include cation exchange, flocculation and agglomeration, carbonation (where lime and carbon dioxide from air form calcium carbonate) and pozzolanic reactions/cementation (where lime, silicon and aluminium form new cementing products) (Choquette et al. 1987). Adding $\mathrm{CaCO}_{3}$ can also influence aggregate stability, probably through cation exchange and flocculation, but not through carbonation and pozzolanic reactions (Berglund 1971). Cation exchange is a relatively rapid reaction that typically takes place within a day (Al-Mukhtar et al. 2012). Pozzolanic reactions are very slow at normal soil temperatures, with reaction times from a week up to years at low temperatures (Al-Mukhtar et al. 2012). If the temperature falls below around $4{ }^{\circ} \mathrm{C}$, pozzolanic reactions can cease until the temperature increases again (Bell 1996).

The reactions between structure lime (pure $\mathrm{Ca}(\mathrm{OH})_{2}$ or in mixtures with $\mathrm{CaCO}_{3}$ ) and clay have been shown to improve aggregate stability, and thereby reduce clay soil erosion (Alakukku and Aura 2006). This leads to decreases in the associated risk of phosphorus losses from soils (Blomquist et al. 2018, Eslamian et al. 2018, Eslamian et al. 2020). A phosphorus leaching mitigating effect of structure lime $(\mathrm{CaO})$ on clay soil of marine origin (permanent cracks in the subsoil) has been demonstrated by Ulén and Etana (2014) and Svanbäck et al. (2014). Gypsum $\left(\mathrm{CaSO}_{4}\right)$ also has the capacity to bring about substantial decreases in turbidity and phosphorus losses (Uusitalo et al. 2012). Quicklime ( $\mathrm{CaO}$ ) application has been shown to improve clay soil structure in laboratory experiments (Berglund 1971) and to increase soil aggregate stability in greenhouse pot experiments with silty/clayey soils 
(Keiblinger et al. 2016). Structure lime $\left(\mathrm{CaCO}_{3}\right.$ mixed with $\left.\mathrm{Ca}(\mathrm{OH})_{2}\right)$ can also result in finer aggregate size distribution in the seedbed (Blomquist et al. 2018).

Results from 30 field trials in southern Sweden (manuscript submitted) showed a significant increase in aggregate stability measured one year after liming, with increasing structure lime application rate. However, the results also revealed that reactions to structure liming differed between soils, with the outcome depending on soil variables, clay content in particular, but also clay mineralogy, soil organic matter content and initial pH. Management factors at application, such as tillage and timing, also played important roles. These management factors are the subject of the present study.

Under Swedish conditions, soils are often most friable and workable in early autumn, resulting in a finer tilth and facilitating contact between structure lime and soil. Compared with surface spreading or combined liming-direct drilling, liming followed by tillage has been shown to have greater effects on aggregate stability (Valzano et al. 2001) and pH (Joris et al. 2016). Field mixing, compared to more thorough mixing of lime into the soil, has been shown to significantly reduce the incidence of clubroot (Plasmodiophora brassicae) (Dobson et al. 1983). This indicates the importance of close contact between soil and lime to achieve the desired soil physical, chemical and biological effects. Soil temperatures are also higher in early (August) than late (September) autumn, providing better conditions for the temperature-dependent pozzolanic reactions (Bell 1996).

The aim of this study was to investigate whether timing of structure liming alters the effect on aggregate stability. The hypothesis tested was that spreading and incorporating structure lime in early autumn results in better aggregation and soil structure stability than structure liming later in autumn.

\section{Materials and methods}

\section{Sites and trial design}

Four field sites with clay soils were selected in different parts of Scania, southern Sweden, in order to cover different soil conditions. The trial at all sites had a randomised block design with four replicates and compared two dates for spreading and incorporation of structure lime: early and normal. Both involved incorporation of a standard dose of $8 \mathrm{t} \mathrm{ha}^{-1}$ Nordkalk Aktiv Struktur (NKAS), a mixture of approximately $80-85 \%$ ground limestone and 15-20\% slaked lime (Table 1).

Table 1. Chemical composition of the liming product Nordkalk Aktiv Struktur (NKAS) used in the trial. Nutrients and compounds are expressed as concentrations of dry matter. Water content 15-25\% depending on storage. Bulk density $1 \mathrm{~g} \mathrm{~cm}^{-3}$. Source: Nordkalk Corp

\begin{tabular}{cccc}
\hline Macronutrient & Concentration (\%) & Micronutrient & Concentration $\left(\mathrm{mg} \mathrm{kg}^{-1}\right)$ \\
\hline $\mathrm{CaO}$ & 50.0 & $\mathrm{Cd}$ & 1.8 \\
$\mathrm{Mg}$ & 1.0 & $\mathrm{Co}$ & 9 \\
$\mathrm{SiO}_{2}$ & 5.4 & $\mathrm{Cr}$ & 26 \\
$\mathrm{Al}_{2} \mathrm{O}_{3}$ & 3.4 & $\mathrm{Cu}$ & 44 \\
$\mathrm{Fe}_{2} \mathrm{O}_{3}$ & 1.5 & $\mathrm{Hg}$ & $<0.02$ \\
$\mathrm{~K}$ & 2.5 & $\mathrm{Ni}$ & 28 \\
$\mathrm{Na}_{2} \mathrm{O}$ & $\mathrm{Pb}$ & 59 \\
$\mathrm{~S}$ & 0.6 & $\mathrm{Zn}$ & 290 \\
$\mathrm{P}$ & 1.7 & & \\
\hline
\end{tabular}

Plots without lime were not included in these trials, both for practical reasons and since application rates $(0,4$, $8,16 \mathrm{t} \mathrm{ha}^{-1}$ ) were tested in parallel studies. Sites, site coordinates and the dates of early and normal liming at the different sites are shown in Table 2.

The pre-crop at all four sites was winter oilseed rape, an early-maturing crop, to enable early and normal liming dates with a reasonable number of days in between under Swedish conditions. On average for the four sites, the early liming date was 20 August, the normal liming date was 14 September and there were 25 days between the dates (Table 2). 
Table 2. Trial site coordinates, dates of spreading and incorporation in autumn 2015, type of tillage equipment used and number of passes. Disc cultivator (Väderstad Carrier), tine cultivators (Väderstad Cultus, Väderstad Opus, Väderstad Swift, Lemken Thorit), combination cultivator with discs and tines (SMS Finisher)

\begin{tabular}{lccccc}
\hline Site & Coordinates & Early date & $\begin{array}{c}\text { Early incorporation/ } \\
\text { tillage }\end{array}$ & Normal date & $\begin{array}{c}\text { Normal incorporation/ } \\
\text { tillage }\end{array}$ \\
\hline Krageholm & $55.49^{\circ} \mathrm{N}, 13.76^{\circ} \mathrm{E}$ & 26 August & $\begin{array}{c}2 \times \text { Väderstad Carrier } \\
+2 \times \text { Väderstad Cultus }\end{array}$ & 15 September & $3 \times$ Väderstad Cultus \\
Krapperup & $56.18^{\circ} \mathrm{N}, 12.70^{\circ} \mathrm{E}$ & 10 August & $2 \times$ Lemken Thorit & 11 September & $2 \times$ Lemken Thorit \\
Råbelöf & $56.08^{\circ} \mathrm{N}, 14.18^{\circ} \mathrm{E}$ & 19 August & $2 \times$ Väderstad Cultus & 7 September & $2 \times$ Väderstad Opus \\
Kornheddinge & $55.63^{\circ} \mathrm{N}, 13.26^{\circ} \mathrm{E}$ & 24 August & $2 \times$ SMS Finisher & 21 September & $2 \times$ Väderstad Swift \\
\hline
\end{tabular}

The structure lime was incorporated within one day after application, with equipment available at the time on the farms at the trial sites (Table 2). Mouldboard ploughing was not carried out after incorporation, and all sites were drilled with winter wheat after the second (normal) spreading and incorporation. All sites were harvested in 2016 for yield measurements, including protein, starch and specific grain weight (data not shown but commented in the Result section)

\section{Soil texture and chemical properties}

Before the start of the study, soil samples were taken from all plots for analysis of soil characteristics (Table 3). The soils at the four sites had $\mathrm{pH}$ values, clay and soil organic matter contents representing normal ranges on agricultural soil in Scania. Soil at three of the sites had normal levels of plant-available phosphorus, while the Råbelöf soil had a very low level of soil phosphorus (Table 3).

Weather data from spreading and sampling years (2015, 2016 and 2018) including mean monthly air temperature and precipitation for the 30-year average period (1991-2020) at official meteorological stations nearest the sites are summarised in Supplementary Tables 1 and 2.

Table 3. Texture and soil nutritional status in topsoil $(0-20 \mathrm{~cm})$ at the four trial sites in August 2015, prior to structure liming.

\begin{tabular}{|c|c|c|c|c|c|c|c|c|c|c|}
\hline Site & SOM $^{a}$ & $\begin{array}{l}\text { Sand }^{b} \\
>60 \mu \mathrm{m}\end{array}$ & $\begin{array}{c}\text { Silt }{ }^{c} \\
2-60 \mu \mathrm{m}\end{array}$ & $\begin{array}{l}\text { Clay }^{d} \\
<2 \mu \mathrm{m}\end{array}$ & $\begin{array}{c}\mathrm{pH} \\
\mathrm{H}_{2} \mathrm{O}\end{array}$ & $\begin{array}{c}\mathrm{P}-\mathrm{AL}^{\mathrm{e}} \\
\mathrm{mg} \mathrm{kg}{ }^{-1}\end{array}$ & $\begin{array}{c}\mathrm{K}-\mathrm{AL}^{\mathrm{e}} \\
\mathrm{mg} \mathrm{kg}{ }^{-1}\end{array}$ & $\begin{array}{l}\mathrm{Mg}-\mathrm{AL}^{\mathrm{e}} \\
\mathrm{mg} \mathrm{kg}^{-1}\end{array}$ & $\begin{array}{l}\mathrm{K} / \mathrm{Mg} \\
\text { quota }\end{array}$ & $\begin{array}{l}\mathrm{Ca}-\mathrm{AL}^{\mathrm{e}} \\
\mathrm{mg} \mathrm{kg}^{-1}\end{array}$ \\
\hline Krageholm & 3.2 & 16.3 & 50.1 & 33.6 & 6.3 & 69 & 139 & 150 & 0.9 & 2660 \\
\hline Krapperup & 3.7 & 58.8 & 19.9 & 21.3 & 7.4 & 66 & 151 & 148 & 1.0 & 3310 \\
\hline Råbelöf & 4.1 & 9.1 & 50.4 & 40.5 & 6.6 & 20 & 169 & 286 & 0.6 & 3610 \\
\hline Kornheddinge & 3.0 & 42.0 & 33.7 & 24.3 & 7.8 & 71 & 138 & 159 & 0.9 & 4200 \\
\hline
\end{tabular}

a Soil organic matter, measured as loss on ignition; ${ }^{\mathrm{b}}$ Wet sieving; ${ }^{\mathrm{c}}$ Calculated as difference between the sand and clay fractions; ${ }^{\mathrm{d}} \mathrm{Hydrometer}$ sedimentation; ${ }^{e}$ Extraction with $0.1 \mathrm{M}$ ammonium lactate + 0.4 M acetic acid, pH 3.75 (Egnér et al. 1960).

\section{Tillage depth and aggregate size distribution after liming}

Tillage depth and aggregate size distribution were measured within three days after lime spreading and incorporation in 2015. Aggregate size distribution was categorised using a total of eight different size classes. First, the tilled soil passed through sieves with coarse mesh in five different size classes (average diameter $>64 \mathrm{~mm}, 32-64 \mathrm{~mm}$, $16-32 \mathrm{~mm}, 8-16 \mathrm{~mm}$ and $<8 \mathrm{~mm})$. The finest fraction $(<8 \mathrm{~mm})$ was passed through sieves with finer mesh in three different size classes (average diameter $>5 \mathrm{~mm}, 2-5 \mathrm{~mm}$ and $<2 \mathrm{~mm}$ ). Unfortunately, the Krapperup site was hit by a heavy thunderstorm (rainfall not measured) shortly after spreading and incorporation at the early date (10 August). As a result, tillage depth could not be measured three days later, on 13 August, and aggregate size distribution could only be measured to shallow depth, and with great difficulty, at the very top of the tilled soil.

\section{Sampling of soil for aggregate stability one year after liming}

Measurements of aggregate size distribution were repeated after harvest in August 2016 approximately one year after spreading and incorporation of the structure lime. Soil samples for aggregate stability testing were taken at the same occasion. Sampling was carried out after two passes with implements resulting in shallow tillage to $6-8 \mathrm{~cm}$ depth. The loose soil samples were passed through sieves in three different size classes $(>5 \mathrm{~mm}, 2-5 \mathrm{~mm}$, $<2 \mathrm{~mm}$ ), as described above. Aggregates with diameter 2-5 mm were placed in dry, aerated containers and stored for rainfall simulations and turbidity measurements. 


\section{Sampling of soil for structure stability three years after liming}

Lysimeters consisting of PVC pipes (height $15 \mathrm{~cm}$, inner diameter $18 \mathrm{~cm}$ ) were centrally placed in the trial plots (one lysimeter per plot) after removal of crop residues in 2018. The lysimeters were forced perpendicularly into the soil using a loader mounted on a tractor. The surrounding soil was then removed with a shovel and the lysimeters were extracted with a margin of undisturbed soil underneath. The top and bottom of the lysimeters were protected with plastic lids and styrofoam, and they were placed in plastic bags and stored at $4{ }^{\circ} \mathrm{C}$ until measurements were performed. At all trial sites, shallow tillage had been performed before sampling, meaning that the top of the soil columns was disturbed. At Krapperup $20 \mathrm{t} \mathrm{ha}^{-1}$ of pig slurry was incorporated on 29 August 2018 seven days before lysimeter extraction.

\section{Aggregate and structure stability and associated risk of phosphorus losses}

Aggregate stability was determined in the laboratory by applying simulated rainfall to air-dried aggregates (average diameter 2-5 mm) (Almajmaie et al. 2017). Irrigation (representing artificial rainwater) was applied at an intensity of 32-39 mm per hour on two occasions 24 hours apart (aggregate irrigations A1 and A2). The irrigation boom moved back and forth continuously without stopping at the ends during irrigation, so the aggregates were subjected to simulated rain for five minutes in the one-hour period. The leachate was collected after each event, and turbidity and electrical conductivity $(E C)$ in the leachate were determined (Turb. A1/A2, EC A1/A2). Before the turbidity measurements, the soil-water suspension was agitated in a shaker for 10 minutes and allowed to sediment for 4.5 hours. A sample of the suspension was then taken at $5.6 \mathrm{~cm}$ depth and the turbidity was measured using a Hach TL 2360 Turbidimeter (Hach, Loveland, Co.). Turbidity in leachate indicates the concentration of clay in the suspension, and is thereby a proxy for aggregate stability and particulate phosphorus losses (Puustinen et al. 2005, Ulén et al. 2012).

The lysimeters taken at the four sites three years after liming (2018) were subjected to two simulated rainfall events (lysimeter irrigations L1 and L2), as described above for soil aggregates, but at an intensity of only 8-11 mm per hour. The irrigation boom moved back and forth during six hours but stopped at the starting position for $120 \mathrm{~s}$ after each pass back and forth, so the lysimeters were subjected to simulated rainfall for only 10 minutes in the six-hour period. The leachate after the second rainfall event was analysed for turbidity (Turb. L2) and also for concentrations of total phosphorus (Tot-P) and dissolved phosphorus ( $\left.\mathrm{PO}_{4}-\mathrm{P}\right)$. Tot- $\mathrm{P}$ was analysed as soluble molybdate-reactive $\mathrm{P}$ after acid oxidation with $\mathrm{K}_{2} \mathrm{~S}_{2} \mathrm{O}_{8}$ (ISO 2005), while $\mathrm{PO}_{4}-\mathrm{P}$ was analysed after pre-filtration using Sarstedt Syringe filter, Filtropur S, PES, pore size: $0.2 \mu \mathrm{m}$, for sterile filtration (ISO 2013), both by colorimetric determination. Particulate phosphorus (Part-P) was estimated as the difference between Tot-P before and after filtration of leachate with the same filters. Only turbidity and EC data from the second simulated rainfall event (Turb. A2, Turb. L2, EC A2) are reported, as differences between treatments were clearer after the second rainfall event.

\section{Statistical analyses}

Analysis of variance (ANOVA) was performed on aggregate size distribution (General Linear Model in Minitab 18, Minitab Inc.) and on log-transformed data on turbidity, EC and concentrations of different phosphorus fractions. Log transformation was necessary to meet the requirement of normal distribution of residuals with the same variance. Following ANOVA, the averages were back-transformed and are reported as absolute and relative values.

\section{Results \\ $\mathrm{pH}$ and yield effects}

Liming significantly increased $\mathrm{pH}(p=0.000)$, plant-available phosphorus $(p=0.000)$ and calcium content $(p=0.000)$ when comparing soil nutritional status before (2015) and after (2016) liming. Mean pH increased by 0.7 units (range 0.4-0.9), from 7.0 to 7.7. In 2016 there were no significant differences between the two treatments (early and normal spreading date). Yield of winter wheat after early liming exceeded that after the normal liming date by $3 \%$, or 0.24 t ha ${ }^{-1}$. However, this difference in yield, and differences in wheat quality parameters such as protein, starch and specific grain weight, were not significant. There were no significant interactions between treatment and site regarding yield of winter wheat in the year following liming. 


\section{Tillage depth and aggregate size distribution at liming}

At the Krapperup site, tillage depth could not be measured at early liming due to rainfall shortly afterwards, which caused the tilled aggregates to integrate with the underlying untilled soil. Tillage depth on average for the four sites was approximately $12 \mathrm{~cm}$ at both liming dates, with consideration of missing values from Krapperup at early liming, and with no significant differences between the dates (Table 4).

Table 4. Average tillage depth $(\mathrm{cm})$ and variation between replicates (range) at the four sites at the early and normal dates for lime spreading and incorporation

\begin{tabular}{lcc}
\hline Trial site & Early spreading & Normal spreading \\
\hline Krageholm & $11.5(10.0-12.5)$ & $11.3(10.0-12.5)$ \\
Krapperup & Not measured & $15.0(12.5-18.0)$ \\
Råbelöf & $15.0(14.0-18.0)$ & $14.6(13.5-16.5)$ \\
Kornheddinge & $7.0(6.5-7.8)$ & $8.3(6.3-9.5)$ \\
\hline
\end{tabular}

Aggregate size distribution showed significant differences between the dates, with a finer tilth at the early liming date compared with the normal date (Fig. 1). There were significant differences in the proportions of size classes $>64 \mathrm{~mm}(p=0.000), 32-64 \mathrm{~mm}(p=0.043), 16-32 \mathrm{~mm}(p=0.000), 8-16 \mathrm{~mm}(p=0.002)$ and $<8 \mathrm{~mm}(p=0.000)$ between the liming dates.

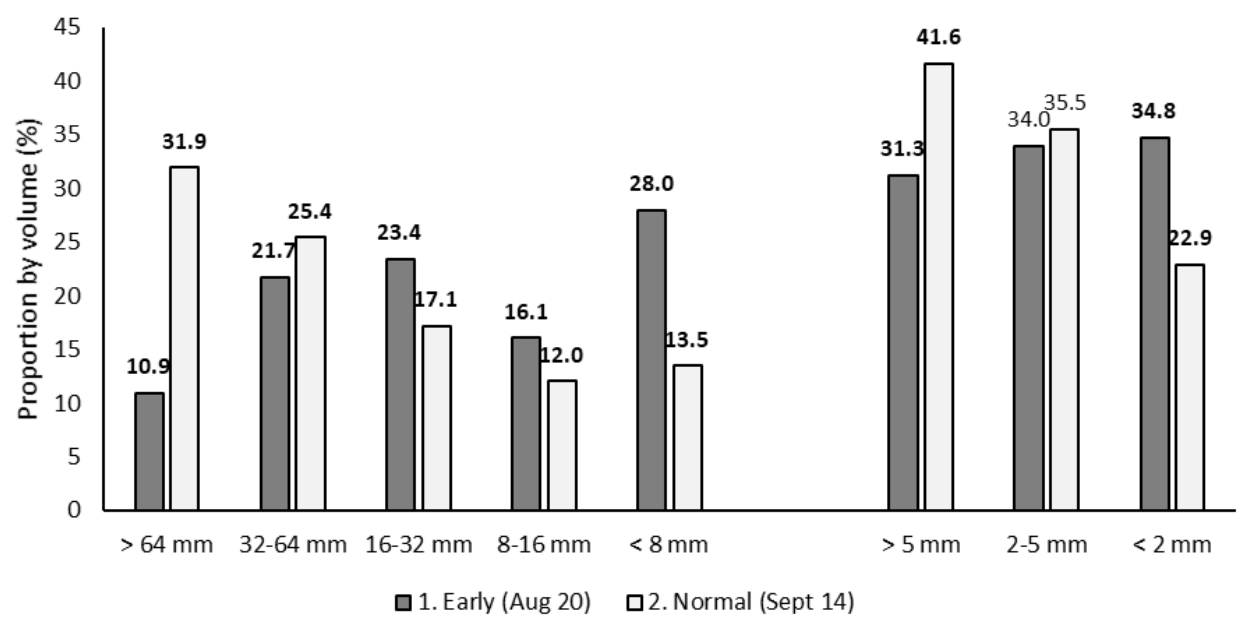

Fig. 1. Aggregate size distribution after spreading and incorporation of structure lime at the early (average 20 August) and normal (average 14 September) dates in 2015. Results of sieving over (left) coarse sieves in five different size classes and (right) fine sieves in three different size classes. Significant differences between treatments (dates) and size classes are indicated in bold. Results and dates are averages for four sites.

However, there were also significant interactions between liming date and site for size fractions $>64 \mathrm{~mm}(p=0.036)$, $8-16 \mathrm{~mm}(p=0.019)$ and $<8 \mathrm{~mm}(p=0.000)$ meaning that the tillage effects were different at the four trials sites. When the finest fraction $(<8 \mathrm{~mm}$ ) was passed once again over sieves with a finer mesh $(>5 \mathrm{~mm}, 2-5 \mathrm{~mm},<2 \mathrm{~mm}$ ), there were significant differences in the fraction $>5 \mathrm{~mm}(p=0.001)$, with no interaction between site and treatment $(p=0.070)$. For the fraction $<2 \mathrm{~mm}$, there were significant differences $(p=0.000)$ and an interaction between liming date and site $(p=0.000)$. For the size fraction $2-5 \mathrm{~mm}$, the same size fraction that was also used in aggregate stability testing in the following year, there was no significant difference between the two liming dates $(p=0.363)$.

\section{Aggregate size distribution and aggregate stability one year after liming}

Aggregate size distribution was measured again approximately one year later, in August 2016. The results showed a significantly increased proportion of aggregates in size fraction $<8 \mathrm{~mm}(p=0.007)$, and a significantly decreased proportion of aggregates in size fraction $>5 \mathrm{~mm}(p=0.007)$ at the normal liming date compared with early liming.

Turbidity and EC results for all sites combined, and for the four separate sites, are shown in Figure 2. Average turbidity, and therefore loss of soil from aggregates with diameter 2-5 $\mathrm{mm}$, after the second simulated rainfall event (Turb. A2) was significantly lower $(p=0.026)$ with early liming than with the normal liming date, with no 
statistically significant interaction between site and liming date $(p=0.414)$. Aggregate soil losses (measured as turbidity) decreased by $11 \%$ with early liming, accompanied by a $12 \%$ increase $(p=0.000)$ in EC (EC A2), again with no significant interaction between site and liming date $(p=0.256)$.

Turb. A2 - average all trials

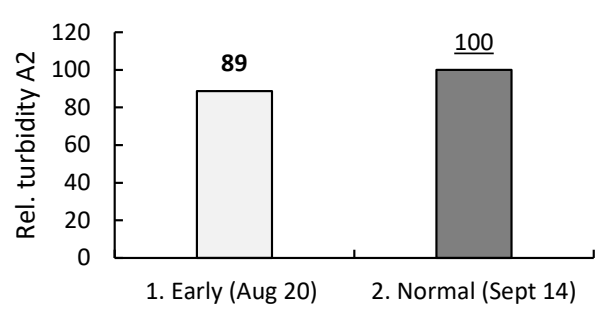

Turb. A2 - Krageholm

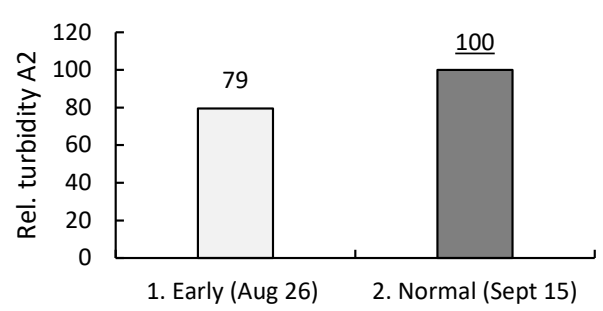

Turb. A2 - Krapperup

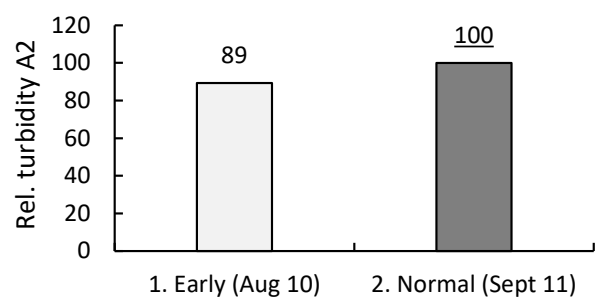

Turb. A2 - Råbelöf

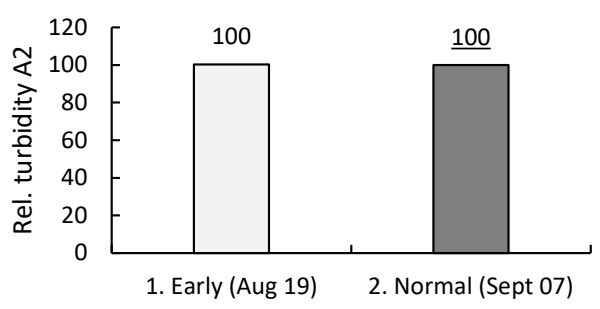

Turb. A2 - Kornheddinge

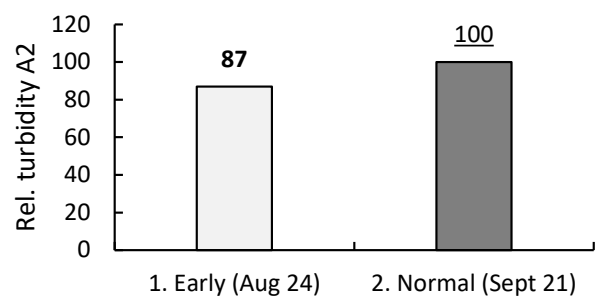

EC A2 - average all trials

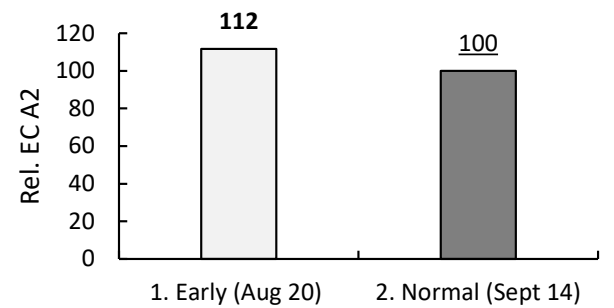

EC A2 - Krageholm

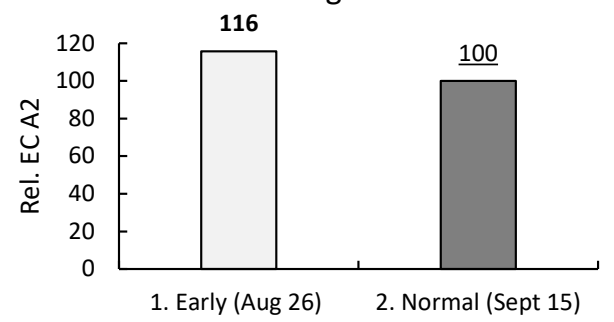

EC A2 - Krapperup

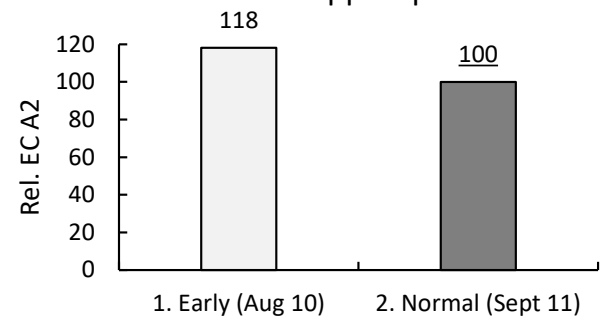

EC A2 - Råbelöf

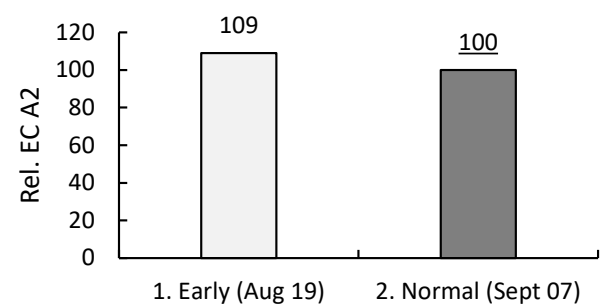

EC A2 - Kornheddinge

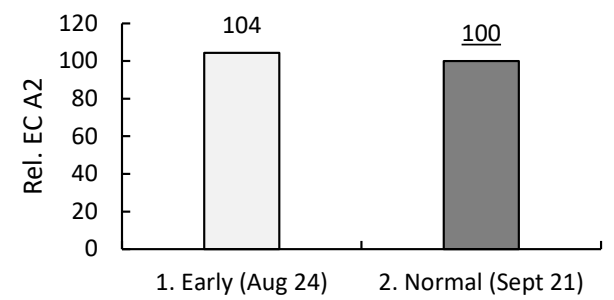

Fig. 2. (Left) Relative turbidity (Turb. A2) values and (right) relative electric conductivity (ECA2) values in leachate from aggregates with diameter $2-5 \mathrm{~mm}$ after a second simulated rainfall event, for all sites and for each individual site. Aggregates sampled in August 2016 after two passes with tine or disc cultivator in plots with early and normal spreading and incorporation of lime in August/September 2015 (normal liming date $=\underline{100}$ ). Significant differences between treatments are indicated in bold. 
At the Krageholm site, there was a tendency ( $p$-value $<0.1)$ for differences between the two liming dates in terms of turbidity $(p=0.061)$ and a significant difference for EC $(p=0.022)$. The Kornheddinge site showed a similar pattern for early and normal liming, with a significant difference between the liming dates for turbidity $(p=0.035)$ and a tendency for differences for EC ( $p=0.055)$ (Fig. 2).

\section{Structure stability and phosphorus concentrations after three years}

There were no significant differences between the two liming dates in terms of turbidity L2 ( $p=0.247)$ or EC L2 $(p=0.602)$ in leachate from the undisturbed lysimeters taken three years after liming. There was a significant interaction $(p=0.010$ ) between site and liming date regarding turbidity $L 2$, making generalisations impossible. Leachate from the lysimeters contained significantly higher concentrations of Tot- $\mathrm{P}(p=0.002)$ and $\mathrm{Part}-\mathrm{P}(p=0.008)$ with the early liming date. However, there was again a significant interaction between site and liming date $(p=0.009$ for Tot-P; $p=0.011$ for Part-P), as seen in the turbidity results for the lysimeters, so no general conclusions could be drawn. For $\mathrm{PO}_{4}-\mathrm{P}$ (dissolved $\mathrm{P}$ ), there were no significant differences or interactions between site and liming date.

\section{Site-specific differences in structure stability and phosphorus concentrations}

Due to the significant interactions between liming date and site, the data on turbidity and phosphorus concentrations in leachate from the lysimeters had to be analysed by site (Table 5). The results for turbidity (structure stability, Turb. L2) were significant for only two of the four sites (Kornheddinge and Krapperup).

Table 5. Turbidity L2, EC L2 and concentrations of total phosphorus (Tot-P), dissolved phosphorus (PO4-P) and particulate phosphorus (Part-P) in leachate from undisturbed lysimeters of soil from the four sites. Significant differences are indicated by different letters. See Table 2 for dates for lime spreading and incorporation.

\begin{tabular}{|c|c|c|c|c|c|c|}
\hline Site & Treatment & $\begin{array}{c}\text { Turb. L2 } \\
\text { NTU }\end{array}$ & $\begin{array}{c}\text { EC L2 } \\
\mu S \mathrm{~cm}^{-1}\end{array}$ & $\begin{array}{l}\text { Tot-P } \\
\left.\mu g\right|^{-1}\end{array}$ & $\begin{array}{c}\text { PO4-P } \\
\mu \mathrm{g} \mathrm{I}^{-1}\end{array}$ & $\begin{array}{l}\text { Part-P } \\
\left.\mu g\right|^{-1}\end{array}$ \\
\hline Krageholm & Early & 147 & 400 & 320 & 30 & 270 \\
\hline Krageholm & Normal & 146 & 367 & 281 & 21 & 244 \\
\hline Krapperup & Early & $115 a$ & 393 & $678 a$ & 305 & $312 a$ \\
\hline Krapperup & Normal & $74 b$ & 462 & $315 b$ & 111 & $167 b$ \\
\hline Råbelöv & Early & 968 & 240 & $463 a$ & 8 & 448 \\
\hline Råbelöv & Normal & 430 & 290 & $281 b$ & 10 & 247 \\
\hline Kornheddinge & Early & $17 \mathrm{~b}$ & 457 & 114 & 48 & 40 \\
\hline Kornheddinge & Normal & $33 a$ & 426 & 128 & 54 & 51 \\
\hline
\end{tabular}

For Kornheddinge, the turbidity in leachate from lysimeters was significantly lower $(p=0.033)$ at the early liming date, whereas for Krapperup it was significantly higher $(p=0.012)$ at the early liming date. The concentrations of the different phosphorus fractions followed the turbidity values reasonably well at Krapperup. For Kornheddinge soil, there were no significant differences between the two liming dates for any phosphorus fraction, whereas for Krapperup the Tot-P and Part-P concentration were significantly higher at the early liming date (Table 5). Råbelöv site also showed significantly increased Tot-P concentrations at early liming date, without turbidity showing significant differences between the treatments.

\section{Aggregate size distribution directly after liming at Kornheddinge and Krapperup}

As pointed out earlier there were interactions between the effect of liming date on aggregate size distribution and site. At Kornheddinge, there were clear differences between the two dates in aggregate size distribution directly after liming (Fig. 3).

For the coarser aggregate classes (Fig.3, left), at the early liming date there was a significantly lower proportion of aggregates $>64 \mathrm{~mm}(p=0.013)$ and a higher proportion of aggregates $<8 \mathrm{~mm}(p=0.008)$ at Kornheddinge. 


\section{Krapperup}

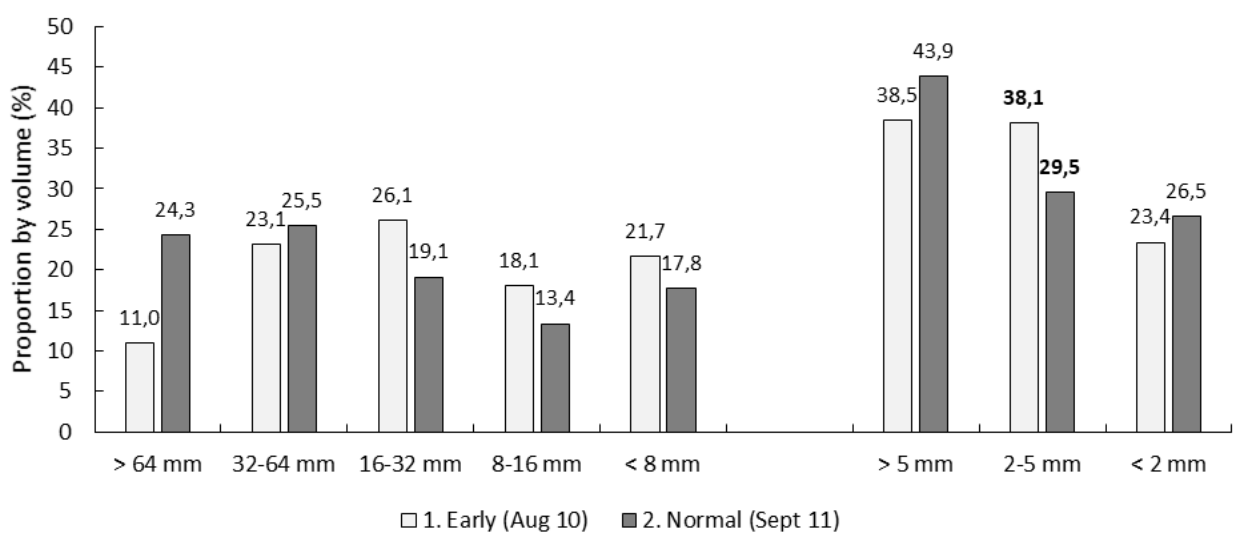

\section{Kornheddinge}

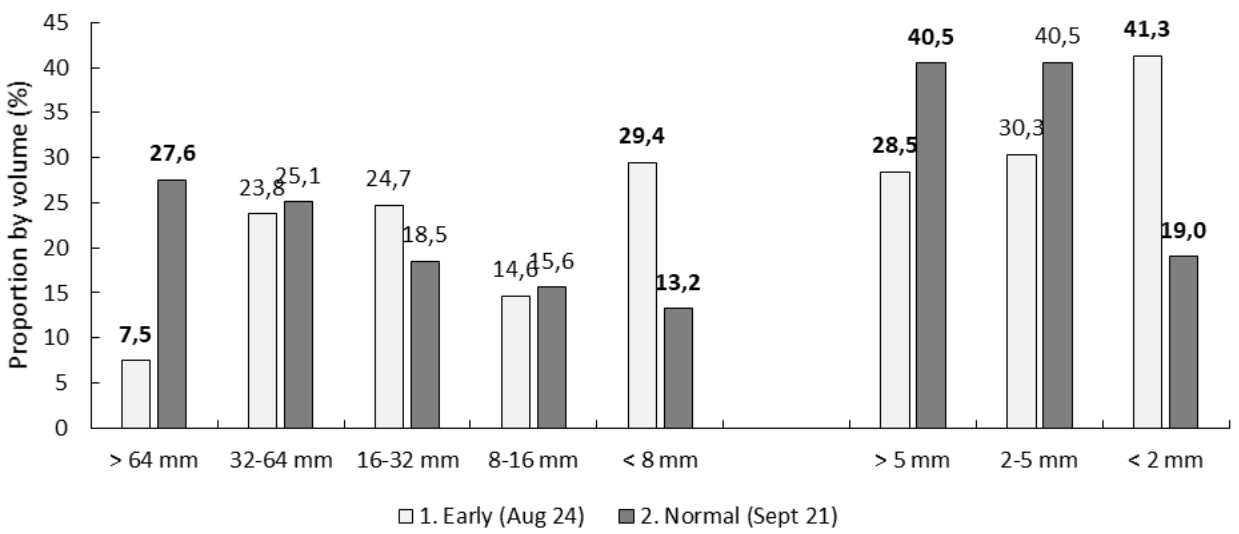

Fig. 3. Aggregate size distribution directly after early and normal spreading and incorporation of structure lime at (upper panel) Krapperup and (lower panel) Kornheddinge, based on sieving over (left) coarse sieves in five different size classes and (right) finer sieves in three different size classes. Significant differences between treatments (dates) and within size classes are indicated in bold.

For the finer aggregate classes (Fig. 3, right), at the early liming date there was a smaller proportion of aggregates $>5 \mathrm{~mm}(p=0.017)$ and a larger proportion of aggregates $<2 \mathrm{~mm}(p=0.001)$. Thus, there was a distinctly finer tilth after early liming compared with liming at the normal date at this site. The tillage implement used for early incorporation at Kornheddinge was a combination cultivator with discs, tines and a reconsolidating packer. For practical reasons, this implement was not available at the normal date, so a tine cultivator was used (Table 2). The less intensive work carried out by the tine cultivator was most probably reflected in the coarser tilth at the normal date.

At Krapperup, there were only significant differences in the aggregate fraction 2-5 $\mathrm{mm}$, with a higher proportion $(p=0.030)$ at the normal liming date. The same combination cultivator with the same adjustments was used at both dates at this site, apparently leaving the tilled soil with approximately the same tilth on both occasions.

\section{Discussion}

\section{Finer tilth at early liming}

This study examined whether timing of structure lime spreading and incorporation influences the effect. In Sweden, an early date (August) normally provides a more workable soil with a finer tilth, and a higher temperature. The solubility of lime would be improved under moist conditions, however the soil must be sufficiently dry to permit tillage with minimised damage to soil structure. The specific hypothesis tested in this study was that spreading and incorporating structure lime in early autumn results in better aggregation and soil structure stability than structure liming later in autumn. 
Measurements of aggregate size distribution immediately after spreading and incorporation of structure lime verified that conditions were more favourable at the early liming date (mean 20 August) than at the normal date (mean 14 September). On average for all four sites, there were significant differences in all aggregate size classes except 2-5 mm diameter, with a distinct shift towards a finer tilth at the early compared with the normal liming date.

Particle size of the lime is a factor that determines the dissolution and the effect on soil properties. A study comparing different particle sizes of magnesium limestone found that the finest fraction $(<0.25 \mathrm{~mm}$ ) was best for increasing soil pH (Álvarez et al. 2009). This fraction also had a significant negative effect on soil phosphorus availability in the short term ( 9 months), which was not the case with coarser fractions (>2 mm, >4 mm) (Viade et al. 2011). If small particle size of the lime product used is a determinant for maximising the surface area available for dissolution, maximum contact between lime and soil should also logically be achieved with a finer tilth compared with a coarser tilth. Since it is reasonable to expect an effect of particle size of both lime and soil, tillage presumably affects the outcome of liming in terms of soil to lime contact area.

\section{Increased aggregate stability at soil surface}

The finer tilth at the early liming date can probably explain the improvement in aggregate stability observed one year after liming. The improvement in aggregate stability achieved by liming can thus be partly attributed to the weather and tillage advantage provided by an early start to autumn tillage. Turbidity (Turb. A2) in leachate was lower (by $11 \%$ ) at early compared with normal liming date and there was no interaction between site and liming date, i.e. all soils showed similar trends. This observation is supported by an increased EC indicating a faster dissolution at the early liming date. In our study there was no treatment without structure lime. However similar findings when examining effects of the interaction between tillage and lime on the outcome of liming have been made in previous studies. Valzano et al. (2001) found greater proportions of aggregates in unstable size classes for nine lime-gypsum treatments in direct-drilled plots than in plots with reduced tillage, and attributed this to the extra tillage operation resulting in more even distribution of lime through the soil. Joris et al. (2016) found that incorporation $(0-20 \mathrm{~cm}$ ) of lime resulted in faster neutralisation than surface spreading, while Conyers et al. (2003) found that the expected increase in $\mathrm{pH}$ due to liming was slower with direct drilling than when lime was incorporated by discing $(0-10 \mathrm{~cm})$. Chan and Heenan (1998) also compared liming-direct drilling with limingincorporation $(0-10 \mathrm{~cm})$ and found significant aggregate stability increases in cultivated soils three years after liming-incorporation, but not after liming-direct drilling. McGrann et al. (2016) found that soil tillage intensity when incorporating lime at different rates to control clubroot (Plasmodiophora brassicae) gave variable results in field trials and concluded that ploughing is a more efficient tillage method. These findings on how tillage interacts with the chemical, physical and biological effects of liming and the results obtained in the present study underline the decisive importance of soil tilth for the outcome of liming.

\section{Temperature effects}

Ambient temperature differed between the two liming dates compared in this study. This might have enhanced the positive effect of the finer tilth at the early liming date, as higher temperature generally leads to higher solubility of solids and faster chemical reactions. Cumulative temperature (i.e. the sum of positive differences between diurnal average temperature and $0{ }^{\circ} \mathrm{C}$ ) at the early liming date exceeded that at the normal date by approximately 400 day degrees. Taking into account that pozzolanic reactions are inhibited below $4{ }^{\circ} \mathrm{C}$ (Bell 1996) and only considering cumulative day degrees above $4{ }^{\circ} \mathrm{C}$, the temperature sum was still 300 day degrees higher at the early liming date. However, in this study the effect on carbonation or cementation in the soils cannot be proven, as no detailed studies were conducted on these reactions at aggregate level.

\section{Concentration versus dilution of lime}

Of the four trial sites, only Kornheddinge had significantly lower turbidity A2 (Fig. 2) at the early liming date, although there was a tendency for turbidity to be lower with early liming at Krageholm. These observations are interesting in light of the differences in tillage depth between the two sites (Table 4). The tillage depth at early liming at Krapperup could not be measured, due to heavy rain shortly after liming, but the tillage equipment used had the same settings on both occasions, so tillage depth should have been similar $(15 \mathrm{~cm})$. At Råbelöf, tillage depth was approximately $15 \mathrm{~cm}$ on both occasions and at Krageholm it was approximately $11 \mathrm{~cm}$ on both occasions, but at Kornheddinge tillage depth was only 7.0 and $8.3 \mathrm{~cm}$ at the early and normal liming date, respectively. The same amount of structure lime was applied at all sites, so it was concentrated in the top 7-8 cm at Kornheddinge but diluted to approximately $15 \mathrm{~cm}$ depth at Krapperup and Råbelöf. The Krageholm site, with intermediate 
tillage depth, also showed intermediate results for turbidity, with a tendency $(p=0.061)$ for lower turbidity values at the early liming date. These results suggest that the effect of liming on aggregate stability can be affected by lime concentration or dilution due to tillage depth. This way of reasoning is in line with Stenberg et al. (2000), who found a much less pronounced soil crust in a year with early crust formation, and therefore considerably higher yields, in treatments with reduced tillage in combination with lime compared with mouldboard ploughing without lime. Measurements of aggregate size distribution one year after liming showed a weak but significant trend for a finer tilth after the normal liming date. This result was surprising and contradicted the initial hypothesis.

\section{No structure stability changes in lysimeters}

Leaching tests on lysimeters from the trial sites taken three years after structure liming revealed a significant interaction between site and liming date regarding turbidity and phosphorus concentrations in leachate from the lysimeters. This finding derived partly from the Krapperup and Kornheddinge sites, which reacted in opposing ways to liming date, possibly due to differences in weather conditions at and after liming. Finer tilth at the early liming date can explain the results at Kornheddinge, but not those at Krapperup, where turbidity in leachate from the lysimeters was significantly higher, by almost $60 \%$, and the concentration of Part-P by almost $90 \%$, at the earIy liming date. These sharp increases may have been the result of unfavourable conditions at and after early liming at Krapperup. At the early date, the tilth at Krapperup was slightly too wet and not perfectly workable but, to create as great a window as possible between the early and normal dates, liming went ahead. In addition, rain fell shortly after spreading and incorporation of lime at the early date, which could have carried soluble calcium down into the soil profile before any major reactions took place (Eslamian et al. 2018). The exact rainfall amount was not recorded at the Krapperup site, but three days after early liming it was impossible to measure the tillage depth as loose and friable aggregates in the lower tilth had disintegrated and more or less blended into the seedbed base.

\section{Management effects}

The lysimeter study indicates that the unfavourable field conditions causing damages to soil structure at early liming at Krapperup in 2015 still remained three years later in 2018 as shown by a significantly higher turbidity L2 at early liming (Table 5) and also significantly higher phosphorus losses (Tot-P and Part-P). Bad soil structure causing cracks can lead to preferential flow which is a dominant pathway for phosphorus losses from clay soils (Djodjic et al. 1999).

The main driving force for the difference in phosphorus losses between the lysimeters from the two sites Krapperup and Kornheddinge was probably that $20 \mathrm{t} \mathrm{ha}^{-1}$ of pig slurry (approximately $10-15 \mathrm{~kg} \mathrm{P} \mathrm{ha}^{-1}$ ) was incorporated on 29 August 2018 at Krapperup, in the midst of the rainy period and only seven days before lysimeter extraction. Surface spreading of mineral fertiliser phosphorus on clay soil after drought conditions poses a risk of phosphorus losses by preferential flow following heavy rainfall (Grant et al. 2019), while cattle slurry application can lead to high losses of soluble phosphorus (Ulén and Mattsson 2003). This was supported by the fact that concentrations in lysimeter leachate of all phosphorus fractions were 6-7 times higher for Krapperup than for Kornheddinge at early liming date.

\section{Timing based on conditions instead of date}

The results obtained for Kornheddinge and Krapperup challenge the current recommendations on structure liming by showing that early liming alone does not necessarily improve soil structure, since weather and soil conditions also need to be favourable. Conditions are likely to be more suitable for structure liming in early autumn than in late autumn but, as shown in the present study, this is not always the case. Therefore, the effects of conditions (e.g. temperature, soil water content, tilth/aggregate size distribution, precipitation, tillage depth etc.) before, at and after structure liming should be further investigated and the recommendations modified accordingly. Such investigations should also cover tillage equipment, as the results for Kornheddinge demonstrate.

\section{Conclusions}

Aggregate size distribution measurements showed a considerably finer tilth at early structure liming and incorporation, with significantly lower proportions of clods (>64 mm) and higher proportions of smaller aggregates $(<2 \mathrm{~mm})$, compared with the normal liming date. A finer tilth enabled closer contact between soil and lime at the early date. 
One year after liming, aggregate stability was significantly higher after early spreading. Increased contact area between lime and soil due to the finer tilth at early liming date can explain this increase in aggregate stability, and indirectly the decreased risk of particulate phosphorus losses, which is the objective with structure liming.

Three years after liming, structure stability in topsoil lysimeters subjected to simulated rainfall events showed no significant differences between the early and normal liming dates. However, there was a strong interaction between liming date and site, indicating different reactions in different soils. Contradictory patterns for two sites with significant differences in turbidity, Part- $\mathrm{P}$ and $\mathrm{PO}_{4}-\mathrm{P}$ concentrations can be attributed to prevailing conditions at the early and normal liming dates. Therefore, early liming date in combination with a finer tilth can give better soil structure and reduce phosphorus losses to surface waters, but only if accompanied by favourable soil conditions.

\section{Acknowledgements}

We would like to express our thanks for both intellectual contributions and field work to Fredrik Hansson and colleagues at HS Skåne Odlarservice and to Lars Wadmark, working at the present time at Nordkalk Corp. We want to thank farmers and farm managers for letting us access their land and for practical help in the field. Jan-Eric Englund supported us with statistical advice for which we are grateful. Thanks also to Johan Knutsson for field work and evaluations in conjunction with a Master's project. Finally we would like to thank the two anonymous reviewers for valuable comments on the manuscript. This work was supported by the County Administration Board of Skåne, through the environment and water protection programme Lokala Vattenvårdsprojekt (LOVA) with grant Lst nr 501-1355-2015, Lantmännen Research Foundation (2015H005) and Stiftelsen Svensk växtnäringsforskning (VX2015-0016).

\section{References}

Al-Mukhtar, M., Khattab, S. \& Alcover, J.F. 2012. Microstructure and geotechnical properties of lime-treated expansive clayey soil. Engineering Geology 139: 17-27. https://doi.org/10.1016/j.enggeo.2012.04.004

Alakukku, L. \& Aura, E. 2006. Zero tillage and surface layer liming promising technique to reduce clay soil erosion and phosphorus loading. In: ASABE 2006 annual international meeting, July 9-12, 2006, Portland, Oregon: paper number 062191, 39. American Society of Agricultural and Biological Engineers.

Almajmaie, A., Hardie, M., Acuna, T. \& Birch, C. 2017. Evaluation of methods for determining soil aggregate stability. Soil and Tillage Research 167: 39-45. https://doi.org/10.1016/j.still.2016.11.003

Álvarez, E., Viadé, A. \& Fernández-Marcos, M. 2009. Effect of liming with different sized limestone on the forms of aluminium in a Galician soil (NW Spain). Geoderma: 152: 1-8. https://doi.org/10.1016/j.geoderma.2009.04.011

Bell, F.G. 1996. Lime stabilization of clay minerals and soils. Engineering Geology 42: 223-237.

https://doi.org/10.1016/0013-7952(96)00028-2

Berglund, G. 1971. Kalkens inverkan på jordens struktur. Lantbrukshögskolan. Uppsala, Institutionen för lantbrukets hydroteknik. (Grundförbättring 24, (särtryck ur 1971:2): 81-93). Lantbrukshögskolan.

Blomquist, J., Simonsson, M., Etana, A. \& Berglund, K. 2018. Structure liming enhances aggregate stability and gives varying crop responses on clayey soils. Acta Agriculturae Scandinavica, Section B-Soil \& Plant Science 68: 311-322. https://doi.org/10.1080/09064710.2017.1400096

Chan, K. \& Heenan, D. 1998. Effect of lime $\left(\mathrm{CaCO}_{3}\right)$ application on soil structural stability of a red earth. Soil Research 36: 73-86. https://doi.org/10.1071/S97054

Choquette, M., Bérubé, M.-A. \& Locat, J. 1987. Mineralogical and microtextural changes associated with lime stabilization of marine clays from eastern Canada. Applied Clay Science 2: 215-232. https://doi.org/10.1016/0169-1317(87)90032-9

Conyers, M., Heenan, D., McGhie, W. \& Poile, G. 2003. Amelioration of acidity with time by limestone under contrasting tillage. Soil and Tillage Research 72: 85-94. https://doi.org/10.1016/S0167-1987(03)00064-3

Djodjic, F., Bergström, L., Ulen, B. \& Shirmohammadi, A. 1999. Mode of transport of surface-applied phosphorus-33 through a clay and sandy soil. Journal of Environmental Quality 28: 1273-1282. https://doi.org/10.2134/jeq1999.00472425002800040031x

Dobson, R., Gabrielson, R., Baker, A. \& Bennett, L. 1983. Effects of lime particle size and distribution and fertilizer formulation on clubroot disease caused by Plasmodiophora brassicae. Plant Disease 67: 50-52. https://doi.org/10.1094/PD-67-50

Egnér, H., Riehm, H. \& Domingo, W. 1960. Untersuchungen über die chemische Bodenanalyse als Grundlage für die Beurteilung des Nährstoffzustandes der Böden. II. Chemische Extraktionsmethoden zur Phosphor-und Kaliumbestimmung. Kungliga Lantbrukshögskolans Annaler 26: 199-215.

Eslamian, F., Qi, Z., Tate, M.J. \& Romaniuk, N. 2020. Lime application to reduce phosphorus release in different textured intact and small repacked soil columns. Journal of Soils and Sediments 20: 1-14. https://doi.org/10.1007/s11368-020-02564-9

Eslamian, F., Qi, Z., Tate, M.J., Zhang, T. \& Prasher, S.O. 2018. Phosphorus Loss Mitigation in Leachate and Surface Runoff from Clay Loam Soil Using Four Lime-Based Materials. Water, Air, \& Soil Pollution 229:97. https://doi.org/10.1007/s11270-018-3750-0 
Grant, K.N., Macrae, M.L. \& Ali, G.A. 2019. Differences in preferential flow with antecedent moisture conditions and soil texture: Implications for subsurface P transport. Hydrological Processes 33: 2068-2079. https://doi.org/10.1002/hyp.13454

Holland, J., Bennett, A., Newton, A., White, P., McKenzie, B., George, T., Pakeman, R., Bailey, J., Fornara, D. \& Hayes, R. 2018. Liming impacts on soils, crops and biodiversity in the UK: A review. Science of the Total Environment 610: 316-332. https://doi.org/10.1016/j.scitotenv.2017.08.020

ISO 2005. ISO6878. Water quality - Determination of phosphorus - Ammonium molybdate spectrometric method.

ISO 2013. ISO15923-1. Water quality - Determination of selected parameters by discrete analysis systems - Part 1: Ammonium, nitrate, nitrite, chloride, orthophosphate, sulfate and silicate with photometric detection.

Joris, H.A.W., Caires, E.F., Scharr, D.A., Bini, Â.R. \& Haliski, A. 2016. Liming in the conversion from degraded pastureland to a notill cropping system in Southern Brazil. Soil and Tillage Research 162: 68-77. https://doi.org/10.1016/j.still.2016.04.009

Keiblinger, K.M., Bauer, L.M., Deltedesco, E., Holawe, F., Unterfrauner, H., Zehetner, F. \& Peticzka, R. 2016. Quicklime application instantly increases soil aggregate stability. International Agrophysics 30: 123-128. https://doi.org/10.1515/intag-2015-0068

McGrann, G.R., Gladders, P., Smith, J.A. \& Burnett, F. 2016. Control of clubroot (Plasmodiophora brassicae) in oilseed rape using varietal resistance and soil amendments. Field Crops Research 186: 146-156. https://doi.org/10.1016/j.fcr.2015.11.013

Puustinen, M., Koskiaho, J. \& Peltonen, K. 2005. Influence of cultivation methods on suspended solids and phosphorus concentrations in surface runoff on clayey sloped fields in boreal climate. Agriculture, Ecosystems \& Environment 105: 565-579. https://doi.org/10.1016/j.agee.2004.08.005

Stenberg, M., Stenberg, B. \& Rydberg, T. 2000. Effects of reduced tillage and liming on microbial activity and soil properties in a weakly-structured soil. Applied Soil Ecology 14: 135-145. https://doi.org/10.1016/S0929-1393(00)00043-3

Svanbäck, A., Ulén, B. \& Etana, A. 2014. Mitigation of phosphorus leaching losses via subsurface drains from a cracking marine clay soil. Agriculture Ecosystem and Environment 184: 124-134. https://doi.org/10.1016/j.agee.2013.11.017

Ulén, B., Alex, G., Kreuger, J., Svanbäck, A. \& Etana, A. 2012. Particulate-facilitated leaching of glyphosate and phosphorus from a marine clay soil via tile drains. Acta Agriculturae Scandinavica, Section B-Soil \& Plant Science 62: 241-251. https://doi.org/10.1080/09064710.2012.697572

Ulén, B. \& Etana, A. 2014. Phosphorus leaching from clay soils can be counteracted by structure liming. Acta Agriculturae Scandinavica, Section B-Soil \& Plant Science 64: 425-433. https://doi.org/10.1080/09064710.2014.920043

Ulén, B. \& Mattsson, L. 2003. Transport of phosphorus forms and of nitrate through a clay soil under grass and cereal production. Nutrient Cycling in Agroecosystems 65: 129-140. https://doi.org/10.1023/A:1022133031584

Uusitalo, R., Ylivainio, K., Hyväluoma, J., Rasa, K., Kaseva, J., Nylund, P., Pietola, L. \& Turtola, E. 2012. The effects of gypsum on the transfer of phosphorus and other nutrients through clay soil monoliths. Agricultural and Food Science 21: 260-278. https://doi.org/10.23986/afsci.4855

Valzano, F., Murphy, B. \& Greene, R. 2001. The long-term effects of lime $\left(\mathrm{CaCO}_{3}\right)$, gypsum $\left(\mathrm{CaSO}_{4} \cdot 2 \mathrm{H}_{2} \mathrm{O}\right)$, and tillage on the physical and chemical properties of a sodic red-brown earth. Soil Research 39: 1307-1331. https://doi.org/10.1071/SR99086

Viade, A., Fernandez-Marcos, M., Nistal, J.H. \& Alvarez, E. 2011. Effect of limestone of different sizes on soil extractable phosphorus and its concentrations in grass and clover species. Communications in Soil Science and Plant Analysis 42: 381-394. https://doi.org/10.1080/00103624.2011.542224

VISS 2021. Water Information Sweden. https://viss.lansstyrelsen.se/ReferenceLibrary/55036 Metod för påverkanstypen Diffusa källor - Jordbruk. Förslag på åtgärder och miljökvalitetsnormer. Accessed 22 February 2021. 